\title{
SELENIUM ENRICHMENT OF BERSEEM PLANTS THROUGH FOLIAR AND SOIL APPLICATIONS.
}

\author{
Mostafa M. M. El-Ghanam, and SalahEl-Din M. E. El-Sisi. \\ Soils, Water \& Environment Research Institute, ARC, Giza, Egypt.
}

\begin{abstract}
A field experiment was conducted during winter seasson of 2005/2006. Egyptian berseem (Trifolium alexandernium) was used as a forage crop. The selenium treatments of foliar spray were added at rates of $0,4,8,12$ and $16 \mathrm{~g} \mathrm{Se} \mathrm{fed}^{-1}$, as sodium selenate $\left(\mathrm{Na}_{2} \mathrm{SeO}_{4}\right)$. Each level of selenium was divided into two doses i.e. $0,2,4,6$ and $8 \mathrm{~g} \mathrm{Se}$ fed $^{-1}$. The cut 1 and cut 2 were sprayed while cut 3 was left without spray. The selenium treatments of soil application were added at rates of $0,12,18,24$ and $30 \mathrm{~g} \mathrm{Se} \mathrm{fed}^{-1}$. The berseem plants were harvested in three cuts.

There were no significant differences between dry matter yield of berseem plants and selenium levels of both foliar spray and soil application. The dry matter production was slightly increased with increasing Se levels of foliar spray but it decreased with increasing Se levels of soil application. Se- concentration in berseem plants was increased with increasing selenium levels of foliar and soil application. The relative increase in Seconcentration in case of foliar spray was $1015 \%$ as the Se levels increased from 0 to $8 \mathrm{~g} \mathrm{fed}^{-1}$, while in case of soil application, they were $821 \%$ when Se levels increased from 0 to $30 \mathrm{~g} \mathrm{Se} \mathrm{fed}^{-1}$. Seuptake by berseem plants increased with increasing selenium levels of foliar and soil application. The relative increases in Seuptake for foliar spray and application were $1042 \%$ and $720 \%$, respectively.
\end{abstract}

Key words: Se-foliar spray-soil application-dry weight- Seconcentration - Se-uptake - berseem plants.

\section{INTRODUCTION}

Since the selenium is an essential nutrient for animals and human, the selenium status of Egyptian soils and plants is generally low (FAO, 1992). Selenium deficiency could be associated with such diseases as cardio vascular disease, cancer, periodontal disease (Wallach and Garmaise, 1979), alcoholic cirrhosis (Sullivan $\boldsymbol{e t}$ al., 1979). There is good evidence that in higher mammals, including man, a selenoenzyme, glutathione peroxidase (Rotruck et al., 1973), prevents periodative cell damage by destroying the hydrogen peroxide generated by dismutation (Valenzuela $\boldsymbol{e t} \boldsymbol{a l . , 1 9 7 7 )}$ and, hence make it possible for human beings to live an atmosphere of oxygen.

Selenium concentration from 25 to $100 \mu \mathrm{g} \mathrm{kg}^{-1} \mathrm{D}$.W have often been considered as levels under which Se deficiency symptoms may appear, while at levels of $2000-5000 \mu \mathrm{g} \mathrm{kg}^{-1} \mathrm{D}$.W or more, toxic effects of Se are possible (Ammerman and Miller, 1975; Mc Dowell et al., 1983; Tan Jianan, 1990 and Yin Zhaohan et al., 1990).

Fayoum J. Agric. Res. \& Dev., Vol. 20, No. 2, July, 2006 
Mostafa M. M. El-Ghanam, and SalahEl-Din M. E. El-Sisi

Gissel-Nielsen (1975) found that a linear correlation between $\mathrm{Se}$ concentration in barley plants and foliar applied selenite $\left(\mathrm{SeO}_{3}{ }^{\circ}\right)$ at rates from 0.5 to $50 \mathrm{~g} \mathrm{Se} \mathrm{ha}^{-1}$. More and Coppenet (1980) observed that using rates of selenium from 10 to $70 \mathrm{~g} \mathrm{ha}^{-1}$ as foliar spray resulted in raygrass tissues having greater than $0.1 \mathrm{mg} \mathrm{Se} \mathrm{kg}{ }^{-1}$ D.W. Gupta et al. (1983) showed that increasing Se levels of foliar application, as sodium selenate $\left(\mathrm{Na}_{2} \mathrm{SeO}_{4}\right)$ from 1.0 to $4.0 \mathrm{Kg} \mathrm{Se} \mathrm{ha}{ }^{-1}$ produced alfalfa timothy having selenium from 27 to $142 \mathrm{mg} \mathrm{kg}^{-1}$ D.W. Gupta and Winter (1989) found that the selenate form $\left(\mathrm{SeO}^{\prime}\right)$ was more effective in increasing plant Se concentration than the reduced selenite form $\left(\mathrm{SeO}_{3}{ }^{\circ}\right)$. MacLeod et al. (1998) found that selenium foliar application by rates of 10 and $20 \mathrm{~g} \mathrm{Se} \mathrm{ha}^{-1}$, as sodium selenate, increased Se content of barley grain and straw and red clover forage.

Gissel-Nielsen (1981) observed that enrichment of P K fertilizers with 120 $\mathrm{g} \mathrm{Se} \mathrm{ha}{ }^{-1}$, in selenite form $\left(\mathrm{SeO}_{3}{ }^{=}\right)$, increased the selenium concentration in barley grain from 0.02 to $0.1 \mathrm{mg} \mathrm{Se} \mathrm{kg}{ }^{-1}$ D.W. Gupta et al. (1983) found that Se addition at rates of $280 \mathrm{~g}$ and $560 \mathrm{~g} \mathrm{ha}^{-1}$ increased Se tissues of timothy, red clover and alfalfa above $0.1 \mathrm{mg} \mathrm{kg}^{-1}$ D.W.

Singh and Singh (1978) and Watkinson and Dixon(1979) found that addition of selenium at rates of higher than $2.5 \mathrm{mg} \mathrm{kg}^{-1}$ soil decreased the growth of wheat (Triticum aestivuml.),sunflower (Helianthu annuusl) and raygrass.

Gupta et al. (1983) showed that foliar application of sodium selenite at rates of 1 to $4 . \mathrm{Kg} \mathrm{Se} \mathrm{ha}^{-1}$ reduced the yield of alfalfa and timothy from 16 to $37 \%$. On the other hand, Wan et al. (1988) did not found significant differences between yield or dry matter production of barley plants and selenium treatments $\left(0.5\right.$ to $1.5 \mathrm{mg} \mathrm{mg} \mathrm{kg}^{-1}$ soil).

The aim of the current work was to select the ideal method of selenium application via foliar spray and soil application. Consequently, studying the relation of these methods with dry matter yield of berseem plants (Trifolium alexandrinum), Se-concentration and Se-uptake as well as reaching to $\mathrm{Se}$ concentration in berseem plants to above $100 \mu \mathrm{g} \mathrm{kg}^{-1}$ and below $3000 \mu \mathrm{g} \mathrm{kg}^{-1}$ that concentration generally considered adequate for preventing Se deficiency in livestock (NAS-NRC, 1983).

\section{MATERIALS AND METHODS}

A field experiment was conducted during 2005/2006 - winter season at the Agriculture farm of Faculty at Moshtohor, Benha University to study the influence of selenium application by foliar spray and soil application on dry matter production, selenium concentration and its uptake by berseem plants. Some physical and chemical properties of the experimental soil were determined according to Klute (1986), Page et al. (1982) and shown in Table (1). The plot area was $1 / 127$ feddan $\left(24 \mathrm{~m}^{2}\right)$ and fertilized with $200 \mathrm{~kg} /$ fed calcium super phosphate before sowing and $30 \mathrm{~kg} /$ fed calcium nitrate after three weeks from germination. 
SELENIUM ENRICHMENT OF BERSEEM PLANTS THROUGH..

Table (1) Some characteristics of the experimental soil.

\begin{tabular}{||l|c||l|l|}
\hline Particle size distribution \% : & & Soluble Ions (mmol $\left.\mathbf{~ L ~}^{-1}\right):$ & \\
\hline Sand & 23.8 & $\mathrm{Ca}^{2+}$ & 5.30 \\
Silt & 18.9 & $\mathrm{Mg}^{2+}$ & 4.20 \\
Clay & 57.3 & $\mathrm{Na}^{+}$ & 3.88 \\
Texture class & Clay & $\mathrm{K}^{+}$ & 0.28 \\
Organic matter $(\%)$ & 2.1 & $\mathrm{CO}_{3}{ }^{+}$ & 0.00 \\
$\mathrm{CaCO}_{3}(\%)$ & 1.5 & $\mathrm{HCO}_{3}^{-}$ & 4.28 \\
pH $(1: 2.5$ soil:water suspension) & 7.9 & $\mathrm{Cl}^{-}$ & 6.10 \\
$\mathrm{EC}\left(\mathrm{dSm}^{-1}\right)$ & 1.4 & $\mathrm{SO}_{4}{ }^{-}$ & 3.28 \\
& & Available Se $\left(\mathrm{mg} \mathrm{kg}^{-1}\right)$ & 0.053 \\
\hline
\end{tabular}

The treatments were: (1) foliar selenium application was added at rates of $0,4,8,12$ and $16 \mathrm{~g} \mathrm{Se} \mathrm{fed}^{-1}$ as sodium selenate $\left(\mathrm{Na}_{2} \mathrm{SeO}_{4}\right)$. Each level of Se was divided into two doses i.e. $0,2,4,6$ and $8 \mathrm{~g} \mathrm{fed}^{-1}$. The cut 1 and cut 2 were only sprayed, while cut 3 was left without spraying. The required amounts of sodium selenate were dissolved in water and sprayed on the plots using sprayer at the application rate of $350 \mathrm{~L} \mathrm{fed}^{-1}$. (2) Soil selenium application, the levels of Se were added at rates of $0,12,18,24$ and $30 \mathrm{~g} \mathrm{Se}$ fed. $^{-1}$. Because the very low of Se application rates, the treatments were mixed with twenty fold size particles of fine sand. All Se treatments were broadcasted by hand according to Gupta and MacLeod (1994). The berseem seeds (Trifolium alexandrinum) were sowing at rate of $30 \mathrm{~kg}$ seeds fed. ${ }^{-1}$. The treatments were distributed in randomized complete block design with three replicates.

The berseem plants were harvested in three cuts. The samples were dried at $60 \mathrm{C}^{\circ}$ and pulverized for chemical analysis. $1.0 \mathrm{~g}$ of the plant materials was digested using $\mathrm{HNO}_{3}$ and $\mathrm{HClO}_{4}$ for Se colormetrically determination according to Olson (1973). Available Se was extracted by AB-DTPA according to Soltanpour (1985) and determined as described by El-Sokkary and Qien (1977). The statistical analysis involved carrying out analysis of variance for results of the experimental treatments; as well as correlationregression analysis for the 45 individual treatments (i.e. treatments \& replications of the whole experiment) was conducted using Minitab program according to Ryan and Joiner (1994).

\section{RESULTS AND DISCUSSIONS \\ Dry matter yield of berseem plants}

Data presented in Table (1) and Fig. (1) show that there were no significant differences between dry matter production of berseem plants and selenium levels of foliar application. The dry matter yield was slightly increased with increasing selenium levels from 0 to $6 \mathrm{~g} \mathrm{Se} \mathrm{fed}^{-1}$ then decreased at level of $8 \mathrm{~g} \mathrm{Se} \mathrm{fed}^{-1}$. The mean values of dry matter production corresponding to cut 1 , cut 2 and cut 3 were, 7.98, 23.00 and 16.74g /40 plants, respectively. The increase in dry matter production of the second cut could be attributed to the low doses of selenium, which stimulate the growth and better tillering. These results are in agreement with those obtained by Wan et al. (1988).

Fayoum J. Agric. Res. \& Dev., Vol. 20, No. 2, July, 2006 
Mostafa M. M. El-Ghanam, and SalahEl-Din M. E. El-Sisi

Fig. 1

Fayoum J. Agric. Res. \& Dev., Vol. 20, No. 2, July, 2006 
SELENIUM ENRICHMENT OF BERSEEM PLANTS THROUGH.. 125

The dry matter production of berseem plants only decreased with increasing selenium levels of soil application compared with the control treatment. However, this reduction was insignificant. The maximum depression was obtained at levels of $18 \mathrm{~g} \mathrm{Se} \mathrm{fed}^{-1}$. These results are in accordance with those obtained by Watkinson and Dixon (1979) and Gupta et al. (1983).

It is worthy to refer that the foliar spray of selenium resulted in dry matter yield of berseem plants amounted to $15.91 \mathrm{~g} / 40$ plants, while soil application produced dry matter production reached of $14.71 \mathrm{~g} / 40$ plants.

Table (2). Dry matter yield of berseem plants (g/40 plants) in relation to foliar and soil application.

\begin{tabular}{|c|c|c|c|c|}
\hline \multirow{2}{*}{$\begin{array}{l}\text { Se Treatment } \\
\left(\text { g Se fed.-1) }^{-1}\right.\end{array}$} & \multicolumn{3}{|c|}{ Dry weight (g /40 plants) } & \multirow[t]{2}{*}{ Mean } \\
\hline & Cut 1 & Cut 2 & Cut 3 & \\
\hline \multicolumn{5}{|c|}{ Foliar application (g Se fed. ${ }^{-1}$ ) } \\
\hline Control & $\overline{7.70}$ & 21.8 & 16.40 & 15.30 \\
\hline 2 & 8.10 & 25.4 & $\begin{array}{l}17.20 \\
\end{array}$ & $\begin{array}{l}16.90 \\
\end{array}$ \\
\hline 4 & 7.30 & 24.30 & 16.60 & 16.07 \\
\hline 6 & 8.30 & 22.80 & 17.10 & 16.07 \\
\hline 8 & 8.50 & 20.70 & 16.40 & 15.20 \\
\hline Mean & 7.98 & 23.00 & 16.74 & 15.91 \\
\hline \multicolumn{5}{|c|}{ Soil application (g Se fed..$^{-1}$ ) } \\
\hline 12 & 7.20 & 18.80 & 19.40 & 15.13 \\
\hline 18 & 5.60 & 15.30 & 20.50 & 13.80 \\
\hline 24 & 5.00 & 19.00 & 15.20 & 14.83 \\
\hline 30 & 5.80 & 23.50 & 14.10 & 14.47 \\
\hline Mean & 6.26 & 19.68 & 17.12 & 14.71 \\
\hline
\end{tabular}

LSD. at 1\%: foliar n.s $\quad$ Soil n.s

\section{Selenium concentration in berseem plants}

In general, foliar spray or soil application of selenium for all treatments resulted in berseem plants having selenium concentration more than $100 \mu \mathrm{g}$ $\mathrm{kg}^{-1}$ D.w principally cut 1 and cut 2 (Table, 3 and Fig. 2). This level of 100 $\mu \mathrm{g} \mathrm{kg}^{-1}$ is generally considered adequate for preventing Se deficiency in livestock (NAS-NRC, 1983). 
Table (3): Selenium concentration in berseem plants $\left(\mu \mathrm{g} \mathrm{kg}^{-1} \mathrm{D} . \mathrm{W}\right)$ in relation to foliar and soil application.

\begin{tabular}{|c|c|c|c|c|}
\hline \multirow{2}{*}{$\begin{array}{c}\text { Se Treatment } \\
\left.\text { (g Se fed. }^{-1}\right)\end{array}$} & \multicolumn{3}{|c|}{ Se-concentration $\left(\mu \mathrm{g} \mathrm{kg}^{-1} \mathrm{D} . \mathrm{W}\right)$} & \multirow[t]{2}{*}{ Mean } \\
\hline & Cut 1 & Cut 2 & Cut 3 & \\
\hline \multicolumn{5}{|c|}{ Foliar application (g Se fed..$^{-1}$ ) } \\
\hline Control & 40 & 29 & 30 & 33 \\
\hline 2 & 201 & 202 & $\overline{41}$ & 148 \\
\hline 4 & 246 & 241 & 53 & 180 \\
\hline 6 & 483 & 395 & 50 & 309 \\
\hline 8 & 516 & 520 & 68 & 368 \\
\hline Mean & 297.2 & 277.4 & 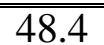 & 207.6 \\
\hline \multicolumn{5}{|c|}{ Soil application (g Se fed. ${ }^{-1)}$} \\
\hline 12 & 210 & 195 & 67 & 157.3 \\
\hline 18 & 252 & 218 & 64 & 178.0 \\
\hline 24 & 346 & 270 & 81 & 232.3 \\
\hline 30 & 498 & 319 & 96 & 304.3 \\
\hline Mean & 269.2 & 206.2 & 67.6 & 190 \\
\hline
\end{tabular}

LSD. at 1\%: $\quad$ Foliar 143.88 Soil 107.44

Selenium concentration in berseem plants was gradually increased with increasing selenium levels of foliar application. The percentage of increased in selenium concentration were, $348 \%, 445 \%, 836 \%$ and $1015 \%$ for foliar selenium treatments of $2,4,6$, and $8 \mathrm{~g} \mathrm{Se} \mathrm{fed}^{-1}$, respectively. Se concentration decreased with increasing cutting numbers in both foliar and soil application. The decrease in the second cut may be due to the dilution effect.

Increasing Se levels of soil application led to a pronounced increase of Se concentration pronoun cedly in berseem plants. The percentage of increases of Se-concentration corresponding to Se treatments of soil application of 12, 18,24 , and $30 \mathrm{~g} \mathrm{Se} \mathrm{fed}^{-1}$ were; $375 \%, 439 \%, 603 \%$, and $821 \%$, respectively. The Se concentration in cut 3 approximately efficient at Se levels of 24 and $30 \mathrm{~g} \mathrm{Se} \mathrm{fed}^{-1}$. The mean values of Se concentration in berseem plants in case of the foliar application was $207.6 \mu \mathrm{g} \mathrm{kg}{ }^{-1} \mathrm{D}$.W, while in case of soil application was $190 \mu \mathrm{g} \mathrm{kg}^{-1}$ D.W. Consequently, foliar spray requires less Se than soil application to obtain the equivalent Se concentration in berseem plants. These results cope with those achieved by MacLeod and Gupta (1995) and El-Ghanam (2005). 
SELENIUM ENRICHMENT OF BERSEEM PLANTS THROUGH.. 127

Fig. 2

Fayoum J. Agric. Res. \& Dev., Vol. 20, No. 2, July, 2006 
The relationship between Se-concentration in berseem plants and foliar spray or soil application could be described by the following equations:
$(\mathrm{r}=0.647 * * *)$

$\begin{array}{ll}\text { Se-concentration }=41.6+41.5 & \text { foliar spray } \\ \text { Se-concentration }=36.0+8.71 & \text { soil application }\end{array}$

$(\mathrm{r}=0.657 * * *)$

Se-uptake by berseem plants

Data in Table (4) reveal the effect of foliar spray of Se as well as soil application on Se-uptake by berseem plants. Se-uptake by berseem plants consistently increased from 0.477 to $5.421 \mathrm{mg} \mathrm{Se} \mathrm{kg}^{-1}$ D.W as the selenium treatments of foliar spray increased from 0 to $8 \mathrm{~g} \mathrm{Se} \mathrm{fed}^{-1}$. The maximum value of Se-uptake was obtained at the second cut (6.277 mg Se kg ${ }^{-1} \mathrm{D}$.W). While the minimum value of Se-uptake was achieved at the third cut $(0.809$ $\mathrm{mg} \mathrm{Se} \mathrm{kg}{ }^{-1} \mathrm{D}$.W). The increase in selenium uptake at the second cut may be ascribed to the increase of dry matter yield. The percentage increase of Seuptake by berseem plants was $1042 \%$ as selenium rates of foliar spray increased from 0 to $8 \mathrm{~g} \mathrm{Se} \mathrm{fed}^{-1}$. These findings are in a agreement with those achieved by Gupta and Winter (1989).

Table (4). Selenium uptake by berseem plants $\left(\mathrm{mg} \mathrm{kg}^{-1} \mathrm{D} . \mathrm{W}\right)$ in relation to foliar and soil application.

\begin{tabular}{|c|c|c|c|c|}
\hline \multirow{2}{*}{$\begin{array}{c}\text { Se Treatment } \\
\left(\text { g Se fed. }^{-1}\right)\end{array}$} & \multicolumn{3}{|c|}{ Se-uptake (mg kg ${ }^{-1}$ D.W) } & \multirow[t]{2}{*}{ Mean } \\
\hline & Cut 1 & Cut 2 & Cut 3 & \\
\hline \multicolumn{5}{|c|}{ Foliar application (g Se fed..$^{-1}$ ) } \\
\hline Control & 0.308 & 0.632 & 0.492 & 0.477 \\
\hline 2 & 1.628 & 5.130 & 0.705 & 2.487 \\
\hline 4 & 1.795 & 5.856 & 0.879 & 2.843 \\
\hline 6 & 4.008 & 9.006 & 0.855 & 4.623 \\
\hline 8 & 4.386 & 10.764 & 1.115 & 5.421 \\
\hline Mean & 2.425 & 6.277 & 0.809 & 3.170 \\
\hline \multicolumn{5}{|c|}{ Soil application ( g Se fed. $^{-1}$ ) } \\
\hline 12 & 1.512 & 3.366 & 1.299 & 2.159 \\
\hline 18 & 1.411 & 3.335 & 1.312 & 2.019 \\
\hline 24 & 1.730 & 5.130 & 1.231 & 2.697 \\
\hline 30 & 2.888 & 7.496 & 1.353 & 3.912 \\
\hline "Mean & 1.569 & 4.051 & 1.137 & 2.252 \\
\hline
\end{tabular}

LSD. at 1\%: $\quad$ Foliar 2.84 Soil 1.57

The same trend was obtained with soil application to enrichment the berseem plants by selenium. Se-uptake by berseem plants was gradually increased with increasing application rates of selenium. The percentage increase of Se-uptake was $720 \%$ when Se rates of soil application increased from 0 to $30 \mathrm{~g} \mathrm{Se} \mathrm{fed}^{-1}$. Se-uptake was positively affected by number of cuts. This increase may be due to the increase in dry matter production. The values mean of Se-uptake for foliar spray and soil application was 3.170 and $2.252 \mathrm{mg} \mathrm{Se} \mathrm{Kg}{ }^{-1}$ D.W, respectively. These results are in accordance with those obtained by Watkinson and Davies (1967), Gupta and MacLeod (1994) and El-Ghanam (2004) who found that increasing rates of Se from 0 to $40 \mathrm{mg} \mathrm{kg}^{-1}$ soil resulted in a significant increase in Se-uptake by soybean

Fayoum J. Agric. Res. \& Dev., Vol. 20, No. 2, July, 2006 
plants. The effect of foliar spray or soil application on Se-uptake by berseem plants was governed with the regression equations as follows:

$\begin{array}{lll}\text { Se-uptake }=0.737+0.600 & \text { foliar spray } & (\mathrm{r}=0.528 * * *) \\ \text { Se-uptake }=0.464+0.104 & \text { soil application } & (\mathrm{r}=0.577 * * *)\end{array}$

The results of this study and in elsewhere refer that selenium application, as foliar spray is the ideal method to enrichment the forage crops with Se such as berseem. Since foliar spray requires a little selenium amount than soaking and soil applications to its increase in plant tissue above $100 \mu \mathrm{g}$ $\mathrm{kg}^{-1}$; the concentration generally considered adequate for preventing Se deficiency in livestock (NAS - NRC, 1983).

\section{ACKNOWLEDGMENT}

The authors wish to express their thanks to Prof. Dr. M.A. El-Abaseri for providing facilities and sincere help during this study.

\section{REFERENCES}

Ammerman, C. B. and Miller, S. M. (1975). Selenium in ruminant nutrition: A review. J. Dairy Sci., 58: 1561-1577.

El-Ghanam, M. M. M. (2004). Interaction between phosphorus and selenium on their availability in soil and contents in soybean plants grown on alluvial clayey soil. Annals of Agric. Sc. Moshtohor, 42(4): 2075-2088.

El-Ghanam, M.M.M. (2005). Effect of soaking and foliar application of selenium on its content in clover plants. Minufiya, J. Agric. Res., 30 (2): 751-759.

El-Sokkary, I. H. and Qien, A. (1977). Determination of Se in soils. Acta Agric., Scandinovica, 27: 285 - 288.

FAO. (1992). Soils Bulletin 65 Food and Agriculture Organization of the United Nations, Rome. Status of cadmium, lead, cobalt and selenium in soils and plants of thirty countries.

Gissel-Nielsen, G. (1975). Foliar application and presowing treatment of cereals with selenite. Z. Pflanzenernahr. Bodenk. 138: 97-105.

Gissel - Nielsen, G. (1981). Foliar application of selenite to barley plants low in selenium. Commun. Soil Sci: Plant Anal., 12: 631- 642.

Gupta, U. C.and Winter, K. A. (1989). Selenite forms of selenium in increasing the concentration in forages and cereals. Canad. J. Soil Sci., 69: 885- 889.

Gupta, U.C. and MacLeod, J.A. (1994). Effect of various sources of selenium fertilization on the selenium concentration of feed crops. Canad. J. Soil Sci., 74: 285-290.

Gupta, U.C.; Kunelius, H.T.and winter, K.A. (1983). Effect of foliar applied selenium on yields and selenium concentration of alfalfa, timothy and barley. Canad. J. Soil Sci., 63: 455-459.

Kluet, A. (ed.) (1986). "Methods of Soil Analysis. Part-1 : Physical and Mineralogical Methods." (2 $2^{\text {nd }}$ ed.) Amer. Soc. Agron., Madison, Wisconsin, U.S.A.

MacLeod, J. A and Gupta, U. C. (1995). Effect of selenium seed treatment on selenium concentrations in soybeans. Can. J. Soil Sci., 75: 287 291.

Fayoum J. Agric. Res. \& Dev., Vol. 20, No. 2, July, 2006 
MacLeod, J.A.; Gupta, U.C.; Milburn, P. and Sanderson, J.B. (1998). Selenium concentration in plant material, drainage and surface water as influenced by Se applied to barley foliage in a barley-red cloverpotato rotation. Canad. J. Soil Sci., 78:685-688.

McDowell, L. R.; Conrad, J. H.; Ellis, G. L. and Looski, J. K. (1983). Minerals for grazing ruminants in tropical regions. Gainesville: Univ. Florida. pp. 86., U.S.A.

More, E. and Coppenet, M. (1980). Teneurs en selenium des plantes fourrgeres influences de la fertilsation et des apports de selenite. Ann. Agron., 31: 297-313.

NAS-NRC (1983). National Academy of Sciences - National Research Council.1983.Selenium in Nutrition, NAS-NRC, Washington, D.C., U.S.A.

Olson, O. E. (1973). Simplified spectrophotometric analysis of plants for selenium. J. Of AOAC, 56: 1073-1077.

Page, A. I.; Miller, R. H. and Keeney, D. R. (eds.) (1982). "Methods of Soil Analysis. Part-2: Chemical and Micrpbiological Properties." $\left(2^{\text {nd }}\right.$ ed.). Amer. Soc. Agron., Madison, Wisconsin, U.S.A.

Rotruck, J. T. ; Pope, A. L.; Gagnther, H. E.; Swanson, A. B.; Hofman, D. G. and Hoekstra, W. G. (1973). Science, 179:588-590. (c.f Gissel-Nielsen et al. (1984). Selenium in soils, plants, and its importance in livestock and human nutrition. Advances in Agron. 37: 379-460).

Ryan, B.F. and Joiner, B.L. (1994). Minitab Handbook. Third Edition, an Imprint of Wadsworth Publishing company Belmont, California, U.S.A.

Singh, M. and Singh, N. (1978). Selenium toxicity in plants and its detoxication by phosphorus. Soil Sci. J., $126: 255-262$.

Soltanpour, P.N. (1985). Use of ammonium bicarbonate DTPA soil test to evaluate elemental availability and toxicity. Commun. Soil Sci. Plant Anal., 16: 323-338.

Sullivan, J. F.; Blotcky, A. J.; Jetton, M. m.; Hohn, H. K. J. and Burch, R. E. (1979). Nutr. J. 109: 1432-1437. (C.f Gissel-Nielsen et al. (1984). Selenium in soils, plants, and its importance in livestock and human nutrition. Advances in Agron., 37: 379-460).

Tan Jianan. (1990). Chemicogeography of some life elements and endemic diseases with an emphasis on China. Pp. 145-157, In: Intl. Symp. Environ. Life Elements and Health, Beijing, 1-5 Nov. 1988.

Valenzuela, A.; Rios, H. and Neiman, G. (1977). Experientia 33: 962-963. (C.f Gissel-Nielsen et al. (1984). Selenium in soils, plants, and its importance in livestock and human nutrition. Advances in Agron., 37: 379-460).

Wallach, J. D. and Garmaise, B. (1979). Trace Subst. Environ. Health, 13: 469-476. (C.f Gissel-Nielsen et al. (1984). Selenium in soils, plants, and its importance in livestock and human nutrition. Advances in Agron., 37: 379-460).

Fayoum J. Agric. Res. \& Dev., Vol. 20, No. 2, July, 2006 
Wan, H.F.; Mikkelsen, R.L. and Page, A.L. (1988). Selenium uptake by some agricultural crops from central California Soils. Pages 25-28in K.K. Tanji, Valoppiand R.C. Woodrings, Eds. Selenium contents in animal and human food crops grown in California. Univ. of Califor. Division of Agric. and Natural Res. Special Publi. No. 3330 oakland, CA.

WatKinson, J.H.and Davies, E.B. (1967). Uptake of native and applied selenium by pasture species .4.Relative uptake through foliage and roots by white clover and browntop. N.Z. J. Agric. Res., 10: 122-133.

Watkinson, J. H. and Dixon, G. M. (1979). N.Z.J. Exp. Agric., 7:321-325. (C.f Gissel-Nielsen et al. (1984). Selenium in soils, plants, and its importance in livestock and human nutrition. Advances in Agron., 37: 379-460).

Yin Zhaohan, Ju Shanjian, Ma xiaoli, Cui Jiambo and cheng Borong . (1990). Se deficiency in environment and keshan disease. PP. 176178, In: Intl. Symp. Environ. Life Elements and Health, Beijing, 1-5 Nov. 1988.

إثراء نباتات البرسيم المصرى بالسيلينيوم من خلال الرش الورقى أو الإضافة الأرضية

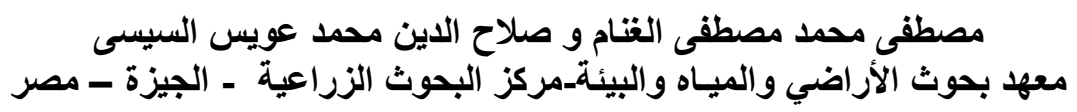

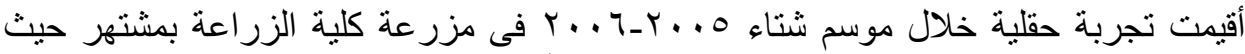

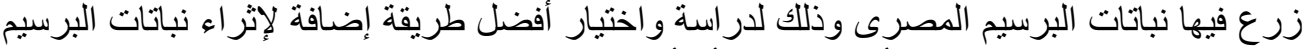

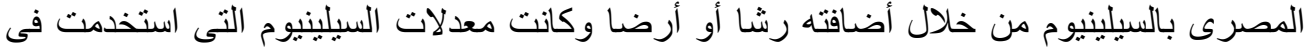

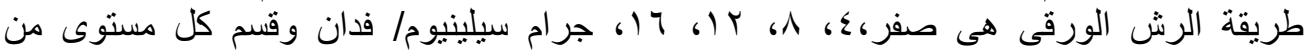

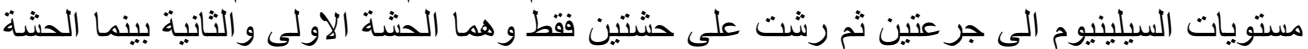

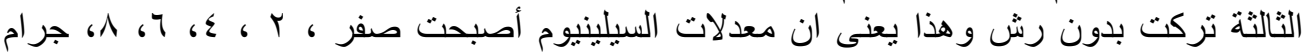

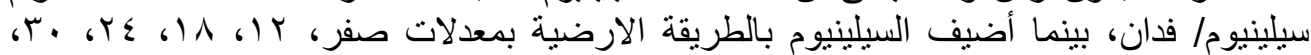

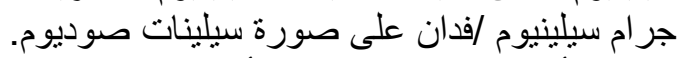

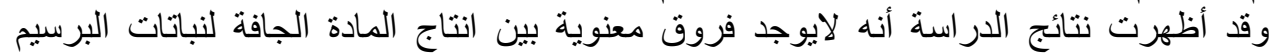

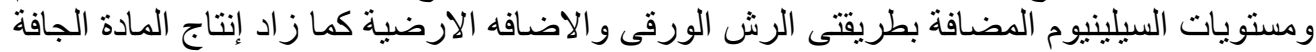

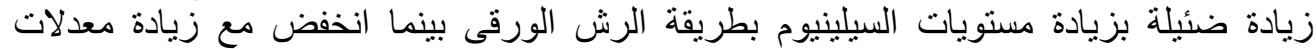

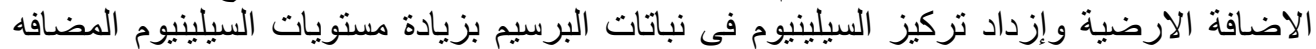

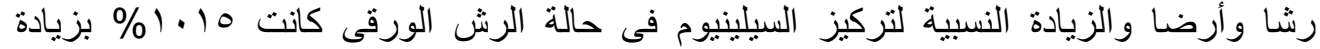

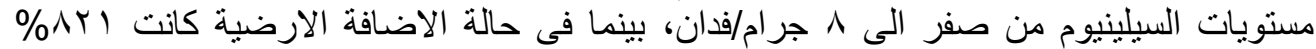

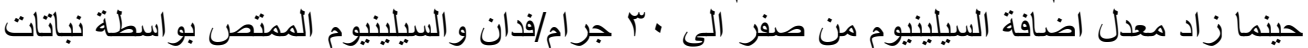

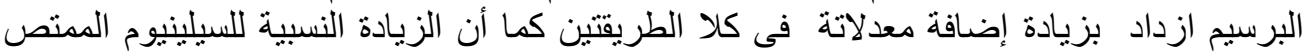

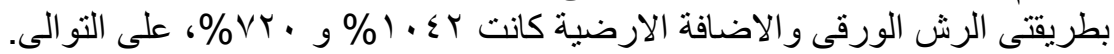

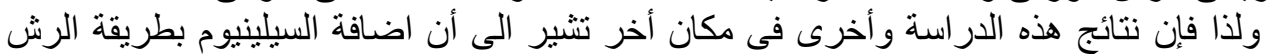

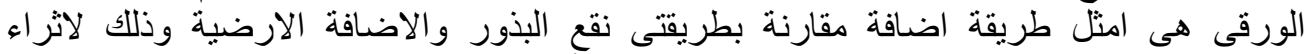

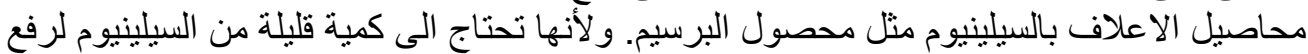

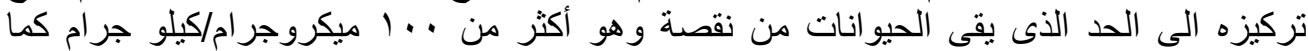

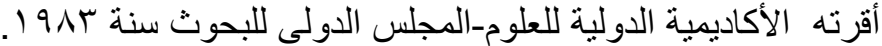

Fayoum J. Agric. Res. \& Dev., Vol. 20, No. 2, July, 2006 
Mostafa M. M. El-Ghanam, and SalahEl-Din M. E. El-Sisi

Dry weight ( $\mathrm{g} / 40$ plants).

Selenium concentration $\left(\mu \mathrm{g} \mathrm{kg}^{-1} \mathrm{D} . \mathrm{w}\right)$.

Dry weight (g/40 plants).

Selenium concentration $\left(\mu \mathrm{g} \mathrm{kg}^{-1} \mathrm{D} \cdot \mathrm{w}\right)$.
Dry weight (g/40 plants).

Selenium concentration $\left(\mu \mathrm{g} \mathrm{kg}^{-1} \mathrm{D} \cdot \mathrm{w}\right)$.

Dry weight (g/40 plants).

Selenium concentration $\left(\mu \mathrm{g} \mathrm{kg}^{-1} \mathrm{D} \cdot \mathrm{w}\right)$.

Fayoum J. Agric. Res. \& Dev., Vol. 20, No. 2, July, 2006 